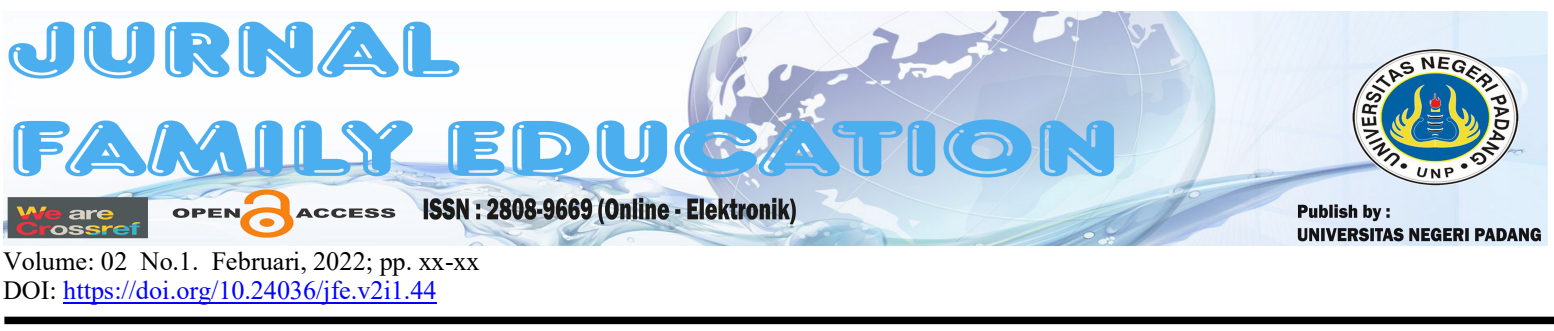

\title{
Hubungan Antara Konsep Diri Peserta Didik Dengan Hasil Belajar Pada Mata Pelajaran Ekonomi Di Kesetaraan Paket C SPNF SKB Kota Solok
}

\author{
Revi Yuni Ashari, Setiawati \\ Universitas Negeri Padang \\ * e-mail: reviyuniazhari@gmail.com
}

\begin{abstract}
The research is the low learning outcomes of students in economics at SPNF SKB Solok City. This condition is believed to be due to the low self-concept of students. This study has the objectives to: 1) see a description of the students' self-concept in the economic learning package C program at SPNF SKB Solok City, 2) see a description of their learning outcomes in the economic learning package $C$ program at SPNF SKB Solok City 3) see the relationship between self-concept students with their learning outcomes in economic subjects Package C Equivalence Program at SPNF SKB Solok City. This research was conducted with a quantitative approach of correlation type which aims to examine the relationship between selfconcept and learning outcomes. The research population is all students registered in Package C 2021 at SPNF SKB Solok City as many as 31 people, the sampling technique is stratified random sampling and taken as many as 80\%, namely as many as 25 people. The data collection method used a questionnaire with a statement list format as a data collection tool, the data were analyzed using the percentage formula and to find the correlation using the Spearmen Rho formula. The results of the study prove that 1) the description of the self-concept of students in the economic subject of the Package C Equivalence Program at SPNF SKB Solok City which is still relatively low 2) the learning outcomes of students in economic learning are low, and 3) there is a significant relationship between selfconcept of students with student learning outcomes in economic subjects Package $C$ Equivalence Program at SPNF SKB Solok City. It is hoped that tutors can develop a positive self-concept for students who take part in the economics subject of the Package C Equivalence Program, the next researcher to examine other variables that can improve the learning outcomes of equivalence education
\end{abstract}

Keywords: Online Learning Media, learning outcomes

\section{PENDAHULUAN}

Pendidikan ialah salah satu kompenen penting bagi setiap manusia dan tidak akan berubah sampai kapanpun, karena pendidikan sangat mendorong dalam mencerdakan bangsa dan menghasilkan kepribadian yang diinginkan.Pendidikan ialah usaha sadar serta tersusun guna melaksanakan kegiatan belajar agar peserta didik aktif menyalurkan keahliannya. Menurut Amar \& Setiawati (2019) Pendidikan memberikan kedudukan yang berguna dalam pemberdayaan 
sumber energi manusia yang selanjutnya berpengaruh besar terhadap kemajuan negara.

Menurut Coombs dalam Puspitasari (2016) pendidikan nonformal merupakan kegiatan pembelajaran yang terorganisir serta terstruktur, selain sistem sekolah yang sebanding, yang dikerjakan secara mandiri serta menjadi bagian utama dari salah satu aktivitas yang luas, yang terencana dicoba agar dapat melayani warga belajar guna meraih tujuan belajarnya.

Menurut Sudjana dalam Trigunawan \& Solfema (2021) hasil belajar ialah sesuatu yang dapat memberi perubahan pada pemikiran, perilaku, dan sikap seseorang dari segi perilaku, pengetahuan, dan keterampilan. Dari pernyataan tersebut, kesimpulan yang dapat diambil ialah bahwa hasil belajar ialah berupa nilai yang didapat oleh warga belajar sebagai gambaran pencapaian atau perubahan dari keterampilan, sikap, dan pengetahuan. Salah satu yang menyebabkan rendahnya hasil belajar peserta didik disebabkan oleh konsep diri. Menurut Shavelson dalam Samosir (2019) menyatakan konsep diri merupakan anggapan seorang mengenai dirinya. Konsep diri jadi aspek internal yang bisa pengaruhi hasil belajar siswa, emosi sosial siswa dan konsep diri dapat memberikan percaya diri lebih dalam mengikuti kegiatan pembelajaran.

Menurut hasil observasi yang pertama pada tanggal 26 juni dan 3 juli 2021 hasil belajar peserta didik di SPNF SKB Kota Solok pada umumnya masih dibawah KKM terutama pada pembelajaran ekonomi. Pada kelas X sebanyak 11 orang yang ikut serta dalam pembelajaran ekonomi sebanyak $80 \%$ anak yang mendapatkan nilai di bawah KKM, sedangkan pada kelas XI sebanyak $65 \%$ anak yang belum memenuhi KKM, jadi hanya 7 dari 13 peserta didik yang tuntas atau diatas KKM.

Konsep diri akademik menurut Peaux dalam Hazizah (2019), ialah salah satu bagian dari konsep diri terutama yang berhubungan dengan masalah akademik. Berdasarkan informasi yang di dapat saat observasi, peserta didik mempunyai konsep diri yang rendah, kondisi ini terlihat ketika melaksanakan ujian dan tes yang diberikan oleh tutor, peserta didik selalu pesimis dalam melaksankan ujian serta tes yang diberikan, peserta didik tidak yakin dengan jawaban ujian dan tes yang diberi oleh tutor dan juga peserta didik kurang menghargai (mencemoh) temennya yang berhasil menjawab pertanyaan tutor.

Dalam hal belajar, diperlukan suatu hal untuk membangun konsep diri yang positif dalam mengembangkan kepercayaan diri. Hal ini sejalan dengan pendapat Cooper dan Sabot (Priyadharma, 2001:18), yang menyatakan bahwa kepercayaan diri ialah harga diri dan kekuatan emosional yang didasarkan pada harga diri. Semakin percaya diri seorang individu, semakin besar kemungkinannya untuk berhasil dalam aktivitas apa pun. Hal ini menunjukkan tingkat konsep diri yang tinggi (agresif), semangat kerja yang tinggi, optimisme, penerimaan pelajaran yang mudah, kompetensi, dan kepercayaan diri dalam berprestasi. Oleh sebab itu, konsep diri sangat berperan dalam keterlibatan kegiatan belajar dalam proses dan menentukan perilaku individu.

Fenomena diatas masih terlihat banyaknya peserta didik yang meraih hasil belajar yang kurang memuaskan atau di bawah KKM, penulis menduga hal ini dipicu oleh konsep diri pada diri peserta didik yang rendah.

\section{METODOLOGI PENELITIAN}

Penelitian ini berjenis kuantitatif melalui pendekatan analisis korelasi. Hal ini dikarenakan penelitian ini bertujuan merumuskan apakah terdapat atau tidak hubungan antar dua maupun lebih variabel (Sukardi 2016). Pada penelitian ini, yang menjadi populasi ialah semua peserta didik yang mengikuti pembelajaran ekonomi pada program kesetaraan paket C di SPNF SKB Kota Solok sebanyak 31 orang, dan diambil sampel berjumlah 25 orang. Pada penelitian ini digunakan teknik kuesioner untuk mengumpulkan data dengan alat berupa angket. Pengolahan data menggunakan rumus persentase dan spearman rho untuk mencari korelasi. Alat yang digunakan dalam mengumpulkan data berupa angket dengan 19 item pernyataan SL, SR, KD, TP. Pada penelitian ini, digunakan rumus persentase untuk menentukan persentase kedua variabel, dan teknik korelasi rank order untuk menentukan rasio antara kedua variabel.

\section{HASIL PENELITIAN}




\section{Gambaran Konsep Diri Peserta Didik pada Program Kesetraraan Paket C di SPNF SKB Kota Solok}

Gambaran Konsep Diri Peserta Didik dilakukan dengan menyebarkan angket pada 25 orang sampel di ungkap melalui sub variabel 1) kepercayaan diri dengan 6 butir penyataan 2) penerimaan diri dengan 6 butir pernyataan dan 3) penghargaan diri dengan 7 pernyataan. Pada pengolahan data, masing-masing item pernyataan memiliki skor alternatif SL: memiliki nilai 4, SR: mendapatkan nilai 3, KD: bernilai 2, dan TP: bernilai 1. Semua data dikelompokkan sesuai persentase dan jumlah rata-rata..

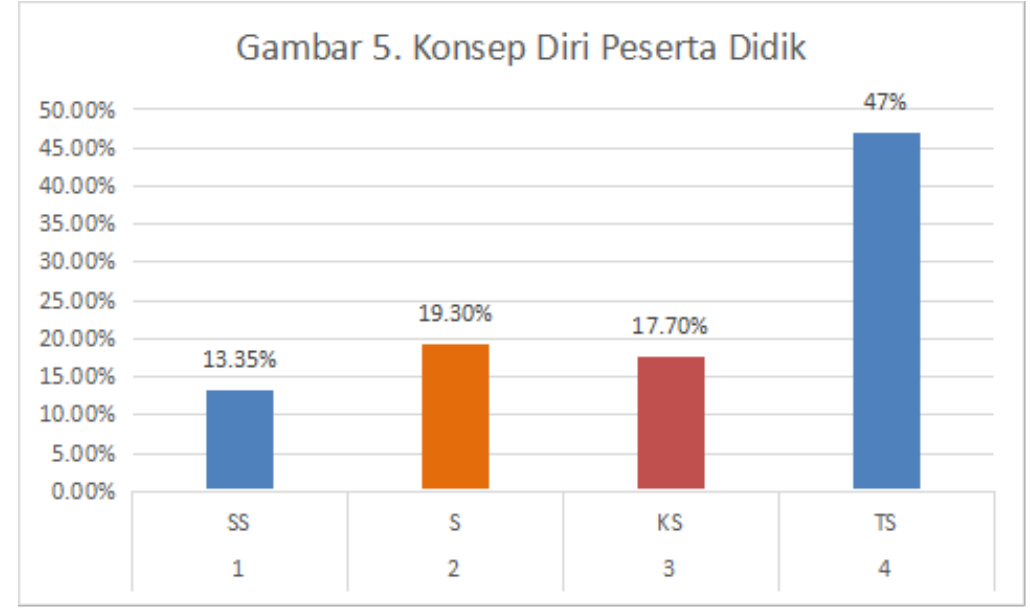

Diagram di atas dijelaskan bahwa konsep diri peserta didik masih dikatakan rendah. Hal tersebut bisa diketahui pada hasil persentase responden paling banyak memilih alternatif jawaban tidak setuju sebanyak 47\%. Dari penjelasan tersebut dapat dijelaskan bahwasanya konsep diri peserta didik pada Program Kesetaraan Paket $\mathrm{C}$ dikategorikan sangat rendah, yaitu tidak setuju sebanyak $47 \%$.

\section{Gambaran hasil belajar peserta didik Didik pada Mata Pelajaran Ekonomi Program Kesetaraan Paket C SPNF SKB Kota Solok}

Dari hasil penelitian dapat dikatakan hasil pembelajaran peserta didik pada mata pelajaran ekonomi dikategorikan rendah, terlihat pada tabel frekuensi terdapat 15 orang dengan hasil belajar rendah, 9 orang yang mendapatkan hasil sedang, dan 1 peserta didik dengan hasil belajar tinggi. Maka bisa disimpulkan bahwa hasil belajar pada mata pelajaran ekonomi pendidikan kesetaraan paket C di SPNF SKB Kota Solok tergolong rendah. Hal ini bisa diamati melalui hasil belajar 15 warga belajar berada pada kategori rendah yang menjadi frekuensi tertinggi.

Tabel 3. Distribusi Frekuensi Hasil Belajar Mata Pelajaran Ekonomi Pendidikan Kesetaraan paket C di SPNF SKB Kota Solok

\begin{tabular}{|l|l|l|}
\hline Interval & Frekuensi & Kategori \\
\hline $65-69$ & 15 & Rendah \\
\hline $70-74$ & 9 & Sedang \\
\hline $75-79$ & 1 & Tinggi \\
\hline
\end{tabular}

Hubungan Antara Konsep Diri Peserta Didik dengan Hasil Belajarnya pada Mata Pelajaran Ekonomi Program Kesetaraan Paket C di SPNF SKB Kota Solok

Pada penelitian ini, hipotesis yang diajukan ialah apakah ada hubungan yang signifikan antara konsep diri peserta didik dengan hasil belajarnya pada mata pelajaran ekonomi program kesetaraan paket C di SPNF SKB Kota Solok Setelah dilakukan pendistribusian frekuensi data, langkah selanjutnya ialah menganalisis data menggunakan rumus yang telah direncanakan pada bab sebelumnya yaitu menggunakan rumus Spearmen Rho dan dapat dilihat hasil hitungnya di bawah ini:

$\mathrm{N}=25$ 
$\sum \mathrm{D}^{2}=728.75$

$$
\begin{aligned}
& \text { rho }=1-\frac{6 \sum D^{2}}{N\left(N^{2}-1\right)} \\
& =1-\frac{6 \times 728,75}{25\left(25^{2}-1\right)} \\
& =1-\frac{4371}{15600} \\
& =1-0,28 \\
& =0,72
\end{aligned}
$$

Interval Koefisien

\begin{tabular}{|c|c|}
\hline $0,00-0,19$ & sangat rendah \\
\hline $0,20-0,39$ & Rendah \\
\hline $0,40-0,59$ & Sedang \\
\hline $0,60-0,79$ & Kuat \\
\hline $0,80-1.00$ & sangat kuat \\
\hline
\end{tabular}

Dari hasil hitungan menggunkan rumus spearmen rho di atas, maka diperoleh $\mathrm{r}_{\text {hitung }}=0.72$, kemudian $\mathrm{r}_{\text {tabel }}$ pada $\mathrm{N}=25$ adalah sebesar 0.409 pada taraf signifikan 95\%. Dengan demikian dapat dikatakan bahwa $r_{\text {hitung }}>r_{\text {tabel }}$. Menurut Sugiyono (2016), jika $r_{\text {hitung }}$ berada pada rentang 0.600.79 maka $r_{\text {hitung }}$ tingkat signifikannya adalah kuat. Pada hasil analisis ini memperoleh $r_{\text {hitung }} 0.72$, maka dapat dikatakan memiliki hubungan signifikan yang kuat.

\section{PEMBAHASAN}

\section{Gambaran Konsep Diri Peserta Didik pada Program Kesetraraan Paket C di SPNF SKB Kota Solok}

Berdasar dari persentase penelitian mengenai gambaran konsep diri peserta didik pada Program Kesetaraan Paket C, ditemukan bahwasanya konsep diri yang ada pada peserta didik saat belajar ekonomi tidak sesuai dengan konsep diri yang seharusnya, dilihat dari banyaknya responden yang memberikan jawaban tidak setuju.

Parnata, Kristiantari, Kt, \& Semara (2014) juga mengemukakan pendapatnya tentang konsep diri, pandangan batin yang ada pada setiap individu mengenai dirinya sendiri, termasuk penilaian pribadi dari jenisnya sendiri. Konsep diri mempengaruhi pandangan seseorang terhadap kondisi fisik dan perilakunya. Ketika berhadapan dengan orang lain, setiap orang bertindak sesuai dengan citra mereka sendiri. Konsep diri jadi aspek internal yang bisa pengaruhi hasil belajar siswa, emosi sosial siswa dan konsep diri dapat memberikan percaya diri lebih dalam mengikuti kegiatan pembelajaran Dengan konsep diri tersebut, orang boleh menilai diri kita positif ataupun negatif. Penilaian itu semua dikarenakan pola tingkah laku yang kita berikan dalam berinteraksi dengan orang di sekitar kita.

Berdasarkan penjelasan-penjelasan yang telah diuraikan tersebut, maka konsep diri dalam pembelajaran tersebut sangat dibutuhkan untuk mencapai tujuan pembelajaran. Konsep diri ini memungkinkan siswa untuk melihat kembali apa yang mereka miliki dalam proses evaluasi, pengukuran, atau penakaran. Dari yang telah dijelaskan di atas bisa peneliti simpulkan bahwa konsep diri siswa masih tergolong rendah. 


\section{Gambaran Hasil Belajar Peserta Didik pada Mata Pelajaran Ekonomi Program Kesetaraan Paket C SPNF SKB Kota Solok}

Dari hasil belajar yang telah diperoleh dari Program Kesetaraan Paket C pada mata pelajaran ekonomi diperoleh suatu kesimpulan bahwasanya nilai atau hasil belajar peserta didik berkisaran antara nilai 61-65, yaitu hampir dari seluruh peserta didik mendapatkan nilai di kisaran angka tersebut. Dari pernyataan tersebut dapat dijelaskan bahwasanya hasil belajar yang diraih oleh peserta didik masih tergolong rendah.

Purwanto dalam Mukhlis \& Irmawita (2021), memaparkan perubahan sikap dan perilaku yang baik yang diperoleh selama tahap evaluasi proses kegiatan pembelajaran merupaka bentuk dari hasil yang diperoleh dari belajar. Hasil belajar yang baik adalah yang memenuhi persyaratan KKM. Hasil belajar yang dicapai siswa melalui tahap evaluasi karena penilaian merupakan kegiatan evaluasi yang dilakukan oleh tutor berdasarkan hasil belajar. Hasil belajar menjadi akibat dari sebab belajarnya seorang peserta didik. Hasil belajar memberikan perubahan pada diri peserta didik seperti pemikiran, perilaku, dan sikap seseorang dari segi perilaku, pengetahuan, dan keterampilan. Perubahan sebagai hasil belajar yang bersifat relatif menetap dan memiliki potensi untuk dikembangkan.

Berdasarkan penjelasan yang dikemukakan di atas dapat diberikan kesimpulan bahwasanya hasil belajar peserta didik pada mata pelajaran ekonomi Program Kesetaraan Paket C SPNF SKB Kota Solok masih tergolong rendah. Hasil belajar diperlukan untuk memberikan perubahan dalam hidup, baik itu dari segi pengetahuan, pengalaman, maupun kecakapan dalam hidup

\section{Hubungan Antara Konsep Diri Peserta Didik dengan Hasil Belajarnya pada Mata Pelajaran Ekonomi Program Kesetaraan Paket C di SPNF SKB Kota Solok}

Berdasar dari pengolahan data yang sudah dilakukan diketahui bahwa konsep diri memiliki hubungan yang signifikan terhadap hasil belajar peserta didik pada mata pelajaran ekonomi Program Kesetaraan Paket C di SPNF SKB Kota Solok dikarenakan $r_{\text {hitung }}>r_{\text {tabel }}$.

Hasil penelitian ini juga dikuatkan oleh teori yang dinyatakan oleh Fernald dalam Sriati (2009), konsep diri yang ada pada diri individu dapat berpengaruh terhadap hasil belajar. Apabila individu merasa memiliki kemampuan untuk mengerjakan sesuatu, maka akan timbul keinginan untuk berusaha menggapai apa yang diinginkan individu tersebut. Harter dalam Qalsum, Nurhayati, \& Yani (2015), juga menunjukkan bahwa inividu yang percaya pada kemampuannya dan termotivasi untuk belajar, akan berpengaruh terhadap kinerja dan hasil belajarnya. Dengan demikian, dapat dikatakan bahwa melalui konsep diri yang positif pada diri akan lebih baik kinerjanya dibandingkan siswa tanpa konsep diri positif.

Dalam penelitian yang telah dilakukan ini, konsep diri berhubungan dengan hasil belajar yang didapat peserta didik untuk mata pelajaran ekonomi Program Kesetaraan Paket C di SPNF SKB Kota Solok. Tingkat konsep diri yang tinggi (agresif), semangat kerja yang tinggi, optimisme, penerimaan pelajaran yang mudah, kompetensi, dan kepercayaan diri dalam berprestasi. Oleh sebab itu, konsep diri sangat berperan dalam keterlibatan kegiatan belajar dalam proses dan menentukan perilaku individu. Dari sebaran angket penelitian yang dilakukan untuk melihat konsep diri peserta didik, maka hasil akhirnya diperoleh bahwa konsep diri peserta didik disana masih tidak sesuai dengan yang seharusnya. Peserta didik dituntut untuk optimis serta semangat dalam belajar meskipun dalam pembelajaran di Program Kesetaraan Paket C. Oleh karena itu, dibutuhkan konsep diri yang positif (semangat dan optimis yang tinggi) selama melakukan pembelajaran pada Program Kesetaraan Paket C khususnya di mata pelajaran ekonomi. Maka disimpulkan semakin baik Konsep Diri Peserta Didik maka Hasil Belajar yang didapat peserta didik akan tinggi pula. 


\section{KESIMPULAN DAN SARAN}

Berdasar pada hasil penelitian dan pembahasan tentang Hubungan antara konsep diri dengan hasil belajar pada mata pelajaran ekonomi Program Kesetaraan Paket C di SPNF SKB di Kota Solok maka dapat disimpulkan sebagai berikut ini. (1)Konsep diri peserta didik pada mata pelajaran ekonomi Program Kesetaraan Paket C di SPNF SKB Kota Solok berada dikategori redah Hal itu dibuktikan dengan hasil yang diperoleh bahwa rendahnya konsep diri dalam menerima diri, kepercayaan diri, dan penghargaan diri. (2)Hasil belajar peserta didik pada mata pelajaran ekonomi tergolong rendah. Hal ini diketahui dari rendahnya hasil belajar yang diraih oleh peserta didik yang dibandingkan KKM yang ada. (3)Terdapat hubungan yang signifikan antara konsep diri peserta didik dengan hasil belajar mata pelajaran ekonomi Program Kesetaraan Paket C di SPNF SKB Kota Solok. Hal itu dibuktikan dengan hasil $t_{\text {hitung }}>t_{\text {tabel }}$.

Berdasar pada kesimpulan tersebut, adapun saran dalam penelitian yang sudah dilakukan ini ialah sebagai berikut: (1) Diharap tutor dapat mengembangkan konsep diri positif kepada peserta didik yang mengikuti pembeljaran ekonomi Program Kesetaraan Paket C. (2) Diharapkan untuk peneliti kedepannya supaya bisa meneliti variabel lain yang dapat meninkatkan hasil belajar.

\section{Daftar Rujukan}

Abdullah, I., \& Jalaluddin. (2007). Filsafat Pendidikan: Manusia, Filsafat dan Pendidikan. Jogjakarta: Ar- Ruzz Media.

Afriana, R., Wisroni, W., \& Setiawati, S. (2018). Hubungan antara Komunikasi Interpersonal Tutor dengan hasil Belajar Bahasa Inggris Warga Belajar Bahasa Inggris Warga Belajar Kelas VIII Paket B di PKBM Sakindo, (2010).

https://doi.org/10.24036/spektrumpls.v1i1.9010

Amar, S., \& Setiawati, S. (2019). Gambaran Pelaksanaan Pendekatan Cooperative Learning Pada Pembelajaran Sosiologi Kesetaraan Paket C. Pakar Pendidikan, 17(1). Retrieved from https://scholar.google.co.id/citations?view_op=view_citation\&hl=en\&user=i81Bd4oAAAAJ \&cstart $=20 \&$ pagesize $=80 \&$ citation_for_view $=\mathrm{i} 81 \mathrm{Bd} 4 \mathrm{oAAAAJ}: \mathrm{hqOj}$ cs7Dif8C

Elfa, E., \& Irmawita, I. (2020). The Relationship Between Instructors' Teaching Skills and The Learning Outcomes of The Learning Community at PKBM Surya Padang. SPEKTRUM: Jurnal Pendidikan Luar Sekolah, 8(4). https://doi.org/10.24036/spektrumpls.v8i4.110102

Etana, N., \& Sunarti, V. (2021). Relationship Between Learning Strategies and Students' Learning Outcomes at Taqwa Pandam TPA. SPEKTRUM: Jurnal Pendidikan Luar Sekolah, 9(4). Retrieved from http://103.216.87.80/index.php/pnfi/article/view/114015/105769

Fitri, L. D. (2017). Hubungan antara Konsep Diri dengan Minat Berwirausaha. KOLOKIUM Jurnal Pendidikan Luar Sekolah, 5(2), 122-131. https://doi.org/10.24036/kolokiumpls.v5i2.30

Hazizah, N. (2019). Permissive Parenting Effect toward Emotional Development of Early Childhood. KOLOKIUM Jurnal Pendidikan Luar Sekolah, 7(1), 1-8. https://doi.org/10.24036/kolokium-pls.v7i1.17

Mukhlis, S. K., \& Irmawita, I. (2021). The Relations of Tutor Teaching Performance and Science Learning Outcome of Learners at Paket B Equivalency Program. SPEKTRUM: Jurnal Pendidikan Luar Sekolah, 9(3). Retrieved from http://103.216.87.80/index.php/pnfi/article/view/113400/105492

Nilam, R., \& Setiawati, S. (2021). The Relationship Between Learning Motivation and Learning Outcomes of 3 in 1 Training Participants of Manual Embroidery Clothing. SPEKTRUM: Jurnal Pendidikan Luar Sekolah, 9(4). Retrieved from http://103.216.87.80/index.php/pnfi/article/view/113875/105766

Oktavia, G., Wisroni, W., \& Syuraini, S. (2018). Hubungan antara Kepuasan Kerja dengan Kinerja Tutor Paket C di PKBM Karang Taruna Kembang Delima. KOLOKIUM: Jurnal Pendidikan Luar Sekolah, 6(1), 54-64. https://doi.org/10.24036/kolokium-pls.v6i1.6

Parnata, I. W., Kristiantari, M. G. R., Kt, D. B., \& Semara, N. (2014). Hubungan Bimbingan 
Belajar Orang Tua dan Konsep Diri dengan Hasil Belajar Matematika Siswa Kelas V SD Gugus V Tampaksiring. E-Journal MIMBAR PGSD Universitas Pendidikan Ganesha, 2(1), $1-10$.

Putri, R., \& Jamna, J. (2021). The Relationship Between Music Accompaniment Learning Media with the Learning Outcomes of the Skills of Minangkabau Traditional Dance Training Participants at the Baiturrahmah Studio Padang City. SPEKTRUM: Jurnal Pendidikan Luar Sekolah (PLS), 9(2).

Qalsum, U., Nurhayati, N., \& Yani, A. (2015). Hubungan Antara Konsep Diri dan Motivasi Berprestasi dengan Hasil Belajar Fisika Peserta Didik SMA di Kota Makassar. Jurnal Sains Dan Pendidikan Fisika, 11(2). Retrieved from

https://media.neliti.com/media/publications/319209-hubungan-antara-konsep-diri-danmotivasi-95a6c072.pdf

Rita, Y., \& Handrianto, C. (2021). Innovation of Digital Learning in Package C Program in Facing the New Normal Education. KOLOKIUM Jurnal Pendidikan Luar Sekolah, 9(1), 20-29. https://doi.org/10.24036/kolokium-pls.v9i1.447

Rola, F. (2006). Hubungan Konsep Diri dengan Motivasi Berprestasi Pada Remaja. Universitas Sumatera Utara. Retrieved from https://repository.usu.ac.id/bitstream/handle/123456789/1938/06010309.pdf?sequence=1\&is Allowed $=\mathrm{y}$

Samosir, V. A. (2019). Hubungan antara Persepsi Dukungan Sosisal Orang Tua dengan Konsep Diri pada Remaja Awal. Universitas Sanata Dharma Yogyakarta. Retrieved from https://repository.usd.ac.id/35907/2/129114141_full.pdf

Sugiyono. (2016). Metode Penelitian Kuantitatif, Kualitatif, dan Kombinasi (Mixed Methods). Bandung: Alfabeta.

Sunarti, V. (2014). Peranan Pendidikan Luar Sekolah dalam Rangka Mitigasi Bencana. Spektrum: Jurnal Pendidikan Luar Sekolah (PLS), 2(2). https://doi.org/10.24036/spektrumpls.v2i2.5044

Trigunawan, I., \& Solfema, S. (2021). Hubungan Antara Kesiapan Belajar dengan Hasil Belajar Peserta Didik Pendidikan Kesetaraan Paket C di PKBM Primadona Desa Cimparuh Kota Pariaman. Jurnal Pendidikan Tambusai, 5(1). Retrieved from https://www.jptam.org/index.php/jptam/article/view/954/858

Yarissumi, Y. (2017). Hubungan antara Konsentrasi Belajar Peserta Didik Dengan Keaktifan Belajarnya pada Bimbingan Belajar Bahasa Inggris Happy Course. KOLOKIUM Jurnal Pendidikan Luar Sekolah, 5(2). Retrieved from http://kolokium.ppj.unp.ac.id/index.php/kolokium-pls/article/view/31/31 